\title{
ПРАВОВЕ ЗАБЕЗПЕЧЕННЯ ЕКОЛОГІЧНОЇ БЕЗПЕКИ В ЄВРОПЕЙСЬКОМУ СОЮЗІ
}

Краснова Ю. А.

У науковій статmі проаналізовано правове гарантування екологічної безпеки в Європейському Союзі. Автором розглянуто особливості формування такого законодавства шляхом аналізу нормативних актів, розроблених в рамках європейських програм з охорони довкілля. Узагальнено роль і значення екологічної безпеки в екологічній політиці Європейського Союзу. Зроблено висновок про необхідність узгодження з вимогами законодавства Європейського Союзу вітчизняних правових норм, котрі визначають та регулюють екологічну безпеку у країні.

Ключові слова: екологічна безпека, правове забезпечення, законодавство Європейського Союзу, законодавство України, правова охорона довкілля, імплементація.

В научной статье проанализировано правовое обеспечение экологической безопасности в Европейском Союзе. Автором рассмотрены особенности формирования такого законодательства путем анализа нормативных актов, разработанных в рамках европейских программ по охране окружающей среды. Проведен обзор роли и значения экологической безопасности в экологической политике Европейского Союза. Сделан вывод о необходимости приведения в соответствие с требованиями законодательства Европейского Союза отечественных правовых норм, определяющих и регулирующих экологическую безопасность в стране.

Ключевые слова: экологическая безопасность, правовое обеспечение, законодательство Европейского Союза, законодательство Украины, правовая охрана окружающей среды, имплементация.

Krasnova Yu. A. Legal provision of environmental security in the European Union

The article is devoted to the analysis of legal provision of environmental security in the European Union. The author considers the peculiarities of the formation of such legislation by analyzing the regulations developed under the seven European environmental programs. The role and importance of environmental safety in the environmental policy of the European Union are generalized.

It was found that the EU environmental legislation does not contain the term "environmental safety", but the concept of "environmental protection", "environmental protection" is widespread, which in our opinion should not be equated, as the latter are defined through a set of measures to ensure the specified ecological safety.

In this regard, it is established that environmental safety is rather the goal of the environmental policy of the European Union, which is achieved through implementation of the principle of sustainable development through the development of legal norms for the preservation, protection and improvement of the environment; public health; reasonable and rational use of natural resources; support for measures at the international level to address regional or global environmental problems, including combating climate change, etc.

Such legal norms are based on the adoption of precautionary measures against chemical, physical and biological effects on the environment that occur during implementation of various types of human activities, in particular, transport, industry, agriculture and more.

It is concluded that it is necessary to bring into line with the requirements of European Union legislation that defines and regulates environmental safety in the country, as they do not contain a single approach to this complex legal category, although, unlike the European Union, enshrines it as constitutional, and at the legislative and regulatory level.

Key words: ecological safety, legal provision, legislation of the European Union, legislation of Ukraine, legal protection of the environment, implementation.

Постановка проблеми та іiі актуальність. Вагомий вплив на формування вітчизняного права екологічної безпеки як системи законодавства здійснює законодавча практика Європейського Союзу (далі - ЄС) із питань охорони довкілля та гарантування екологічної безпеки. Законодавство ЄС традиційно називається правом охорони довкілля та прямо не закріплює усталеного для українського законодавства терміна «екологічна безпека». Однак на розвиток цього напряму законодавства на європейському рівні стала ситуація 3 небезпечним характером надмірних викидів забруднюючих речовин в атмосферу, скиданням промислових і побутових стічних вод у водойми, що призвело до збільшення кількості захворюваності людей та навіть смертності [1].

(С) Краснова Ю. А., 2020 
Негативні зміни якості життя населення й великі економічні втрати від антропогенного впливу з усією серйозністю поставили питання про необхідність формування екологічної політики держав Європи. Вже у 60-і роки XX століття в окремих європейських країнах почали ухвалюватись екологічні нормативи щодо вмісту забруднюючих речовин у природних ресурсах, а також створюватись урядові організації, які займаються проблемами довкілля. Перша державна установа з охорони довкілля міністерського рівня була утворена у Швеції в 1969 році, а в середині 70-х років XX століття - в низці країн ЄC, до складу якого на той час уходило 9 держав, були засновані спеціалізовані природоохоронні відомства [2, с. 147].

Однак виявилось, що в межах однієї держави більшість екологічних проблем вирішити неможливо, оскільки зміна клімату, виснаження озонового шару й забруднення морів, земель, повітря не знають державних кордонів. Стало зрозумілим, що охорона довкілля має не тільки національний, а й міждержавний аспекти. Для вирішення екологічних проблем, котрі мають транскордонний i глобальний характер, Європейському співтовариству потрібно було створити міждержавні структури й розробити єдину екологічну політику, яка станом на сьогодні нараховує вже сім етапів свого становлення [3, с. 22-26; 4, с. 13].

Завдяки положенням таких програм у ЄC на сьогодні розроблено сотні нормативних актів, спрямованих на їх реалізацію. Можна зробити висновок, що більшість із них спрямовані на сферу гарантування екологічної безпеки.

Ïх основу становлять акти «первинного» права (установчі документи), акти «вторинного» права (регламенти, директиви, рішення), акти «М'якого» права (резолюції, рекомендації) та акти тлумачення норм права ЄC (рішення Європейського Суду) [5, с. 688-691].

Аналіз останніх досліджень i публікацій. У науково-правовій літературі окремим питанням розвитку законодавства, яке регулює гарантування екологічної безпеки загалом та в ЄC зокрема, надавалась увага в роботах таких науковців: В.І. Андрейцева, Р. Брадена, А.П. Гетьмана, С. Делбі, Дж. Барнетт, Р. Метью, Р. Робертсона, Дж. Дейлса, Л. Піттермана, О. Скарлато, Дж. Стіглера, І. Телеш, С.М. Кравченко, О.С. Колбасова, А.В. Кукушкіна, В.І. Лозо, Є.А. Нестеренко, Н.Р. Малишевої, М.М. Мікієвич, С.М. Орєхова, А.С. Тимошенко, А.С. Шишко, О.А. Шомпол та інших. Однак комплексного наукового дослідження із цієї тематики ще не було проведено.
Метою статті $\epsilon$ спроба автора виокремити 3-поміж природоохоронних норм законодавства ЄC правові норми, що спрямовані на гарантування екологічної безпеки.

Виклад основного матеріалу. Розвиток політики гарантування екологічної безпеки ЄС тісно пов'язаний із розвитком його внутрішнього ринку. Витоки політики гарантування екологічної безпеки знаходять своє місце в Директиві ЄС, ухваленій ще в 1967 році, щодо узгодження класифікації та маркування небезпечних хімічних речовин [6], а самі цілі та принципи захисту визначені в Договорі про створення Європейського Союзу [7]. Проте активний розвиток цієї політики відбувся з 1973 року після Стокгольмської конференції ООН, яка відбулась у 1972 році [8], що відзначилась ухваленням Декларації щодо програми дій із довкілля, в якій визначалися цілі і принципи, а також були сформульовані пріоритетні питання охорони довкілля, вирішення яких вимагалось невідкладно.

Однак, аналізуючи екологічне законодавство ЄС, ми не зустрінемо поняття «екологічна безпека», натомість широко розповсюдженим $€$ поняття «охорона довкілля», «охорона довкілля», які на нашу думку, не варто прирівнювати, оскільки останні визначаються через сукупність заходів, що мають забезпечувати вказану екологічну безпеку [9, с. 54-79].

Необхідно зазначити, що типовим для європейського природоохоронного законодавства $€$ той факт, що порівняно з іншими сферами законодавства ЄС, велике значення надається загальноприйнятим принципам, які $\epsilon$ базою розвитку норм екологічного права. Формування політики ЄC у сфері охорони довкілля та гарантування екологічної безпеки здійснюється поетапно шляхом ухвалення так званих Програм дій із довкілля, які хоча й носять рекомендаційний характер, але завдяки встановленню чітких напрямів, цілей i принципів екологічної політики ЄC, разом із їх детальним описом і графіком реалізації сприяють розвитку та імплементації екологічного законодавства [10, с. 13].

На основі ухвалених семи програм дій із довкілля ми виділяємо сім етапів розвитку та становлення політики гарантування екологічної безпеки в ЄС.

Перший етап розвитку починає свій відлік із моменту утворення Європейського Співтовариства і триває до 1976 року включно. У цей період відбувається реалізація угод про створення Європейського Співтовариства та Першої програми дій із довкілля, яка була ухвалена на початку 1973 року. 
Вона може вважатись першим офіційним документом, у якому були сформульовані основні принципи європейської політики у сфері охорони довкілля. Перша програма дій зосереджувала увагу на зменшенні та запобіганні забруднення та відновлені небезпечного для життя та здоров'я людини стану довкілля [10, с. 13].

Із метою досягнення поставлених цілей було ухвалено низку нормативних актів. Зокрема, 20 березня 1970 року була ухвалена директива Ради Міністрів ЄС 70/220/ЄЕС про наближення законів держав-членів щодо заходів проти забруднення повітря автомобілями [11]. Цією Директивою з метою скорочення викидів автомобілями шкідливих речовин атмосферу, які можуть уплинути на здоров'я людини, встановлювались нормативи гранично допустимих викидів автомобілями.

Із метою обмеження шумового забруднення Комісія ухвалює Директиву 73/350/ЄЕС від 7 листопада 1973 року про адаптацію до технічного прогресу Директиви Ради від 6 лютого 1970 року про наближення законів держав-членів, котрі стосуються стандартів рівня шуму та системи вихлопу транспортних засобів [12]. Цією Директивою встановлено принцип, що транспортний засіб повинен бути розроблений та сконструйований таким чином, щоб його рівень шуму не перевищував установлені межі.

Протягом 1975-1976 рр. було ухвалено низку директив ,спрямованих на запобігання, зменшення та встановлення контролю за забрудненням водних об'єктів, а саме: Директива Ради 75/440/ЄЕС про вимоги до якості поверхневих вод, призначених для забору питної води в державах-членах ЄC [13]; Директива Ради 76/160/ЄEC про якість води для купання [14]; Директива Ради 76/464ЄЕС щодо забруднення, спричиненого деякими небезпечними речовинами, які скидаються у водне середовище $€ C$ [15].

Крім того, в межах реалізації Першої програми дій Європейським Співтовариством було підписано один із перших міжнародно-правових документів Міжнародну конвенцію про охорону Середземного моря від забруднення у 1976 році [16].

Другий етап починається в 1977 році й закінчується в 1982 році. За цей час ухвалюється й реалізується Друга програма дій ЄС «Продовження та імплементація політики Європейського співтовариства і програма дій із довкілля» [17]. Друга програма дій $\epsilon$ своєрідним доповненням Першої. Вона визначила основні цілі екологічної політики $\in C$, котрі полягають у запобіганні, зменшенні та уникненні забруднення, підтримці екологіч- ного балансу й забезпечення захисту біосфери; уникнення небезпечного використання природних ресурсів, яке може суттєво вплинути на довкілля; пошуку вирішення державних екологічних проблем за межами $€ C$, на світовому рівні.

Відповідно до Другої програми дій на рівні $€ С$ були ухвалені такі нормативні акти. 3 метою встановлення належного рівня правового регулювання граничних норм якості повітря ухвалюється Директива Ради 80/779/ЄЕС від 15 липня 1980 року про граничні норми якості повітря та настановні величини сірчистого газу й зважених частинок [18]. Задля обмеження шумового забруднення на цьому етапі ухвалюється Директива Ради 80/51/ЄЕС про обмеження шуму від дозвукової авіації [19].

Із метою встановлення контролю за якістю води, визначення стандартів, яким повинна відповідати вода, призначена для споживання, та з метою захисту водних ресурсів від забруднення Європейським Співтовариством було ухвалено: Програму дій щодо контролю та зменшення забруднень від вуглеводнів, які потрапили в море (1978 рік); Директиву Ради 78/659/ЄЕС від 18 липня 1978 року щодо якості прісних вод, що потребують захисту або покращення для підтримки існування риби (з поправками); Директиву Ради 79/869/ЄЕС від 9 жовтня 1979 року про методи вимірювання й частоту взяття проб та аналізів поверхневих вод із метою відведення питної води в державах-членах; Директиву Ради 80/68/ЄЕС про захист підземних вод від забруднення окремими небезпечними речовинами; Директиву Ради 80/777/ЄЕС Ради від 15 липня 1980 про наближення законів держав-членів, які стосуються експлуатації й маркетингу природних мінеральних вод; Директиву Ради 80/778/ЄС від 15 липня 1980 року щодо якості води, що призначена для споживання населенням.

Для збереження природних ресурсів, сільського господарства, рибного господарства, економічного розвитку та співпраці ухвалюються такі законодавчі акти: Директива Ради 78/659/ЄЕС від 18 липня 1978 року про якість прісних вод, які потребують захисту або покращення з метою збереження рибних ресурсів; Директива Ради 79/409/ЄЕС про збереження диких птахів; Директива Ради 79/923/ЄЕС від 30 жовтня 1979 року щодо вимог до якості вод, придатних для життя молюсків; Резолюція Ради від 2 квітня 1979 року, що стосується Директиви 79/409/ЄЕС про захист диких птахів; Регламент Ради 348/81 про спільні правила імпорту китів чи інших китових продуктів; Рішення Ради 81/691/ЄЕС про підписання Конвенції про збереження морської флори та фауни 
Антарктиди; Рішення Ради 82/72/ЄЕС про підписання Конвенції про охорону дикої флори та фауни i природних середовищ існування в Європі; Рішення Ради 82/461/ЄЕС про підписання Конвенції про збереження мігруючих видів диких тварин [10, с. 14-15].

Окрім цього, було ратифіковано Конвенцію про охорону дикої флори та фауни і природних середовищ існування в Європі [20] та Конвенцію про транскордонне забруднення повітря на великі відстані [21] в 1979 році.

Третій етап тривав із 1983 року по 1986 рік включно. 7 лютого 1983 року було ухвалено Третю програму дій Європейського Союзу з довкілля [22], яка містила принципово нові положення. Третя програма дій визначила необхідність подальшої інтеграції екологічної політики в інші сектори політик ЄС; необхідність посилення превентивних аспектів екологічної політики, за таких умов особливе значення надавалось оцінці впливу на довкілля; виділення низки галузей, дії в яких були визнані пріоритетними для покращення довкілля (зниження забруднення морської і прісної води, транскордонне забруднення, небезпечні хімічні речовини і препарати, відходи, забруднення ґрунтів тощо); формулювання низки положень, які Європейська Комісія повинна розглядати як базові під час підготовки своїх пропозицій.

Із метою реалізації визначених Третьою програмою дій принципів ухвалені наступні законодавчі акти. 12 червня 1986 року було ухвалено Директиву 86//278/ЄЕС про захист довкілля та, зокрема, ґрунту у випадках використання в сільському господарстві осаду стічних вод [23]. Задля легкого виявлення та ідентифікації небезпечних хімічних речовин на європейському рівні було ухвалено Рішення Комісії 85/71/ЄЕС від 21 грудня 1984 року про список потенційно небезпечних хімічних речовин, згідно з Директивою Ради 67/548/ЄЕС про зближення правових приписів, регламентів та адміністративних положень щодо класифікації, пакування й маркування небезпечних речовин [24]. Відповідно до цієї Директиви, зокрема, встановлено критерії, завдяки яким хімічні речовини та препарати визначаються як такі, які $є$ небезпечними для людини та природного довкілля. В межах Третьої програми дій та на виконання Конвенції про запобігання забрудненню морського середовища із джерел, розташованих на суші, було ухвалено Рішення Ради 85/613/ЄЕС від 20 грудня 1985 року про ухвалення, від імені Спільноти, програм та заходів щодо скидання ртуті та кадмію [25].
Наступний етап розпочався в 1987 році і тривав до 1992 року включно. 19 жовтня 1987 року ухвалюється Четверта програма дій із довкілля [26]. Вона надає більше уваги пошуку нових можливостей для інтеграції екологічної політики в інші політики Європейського Союзу, звертаючи особливу увагу на такі сфери діяльності, як розробка екологічних стандартів, управління всіма видами впливу на довкілля, забезпечення ширшого доступу громадськості до інформації та поширення екологічної інформації, а також розвиток екологічної освіти, біотехнологія й управління природними ресурсами, охорона особливих природних територій, наприклад гірських районів і берегових зон.

На виконання цих заходів Європейським Союзом ухвалюється низка законодавчих актів, котрі стосуються питань використання та охорони водних ресурсів, атмосферного повітря, обмеження акустичного впливу (шуму), контролю й поводження з відходами й небезпечними речовинами, охороною флори й фауни. Були також упроваджені важливі процедури з охорони довкілля, включно з оцінкою впливу на довкілля й обов'язковим повідомленням Комісії про певні екологічно небезпечні дії [10, с. 16].

П'ятий етап розвитку екологічного права Європейського Союзу пов'язаний із реалізацією протягом 1993-2001 років П'ятої програми дій із довкілля [27]. Особливу увагу у П'ятій програмі дій Європейського Союзу з довкілля надавалось таким основним сферам дій, як стале управління природними ресурсами, інтегрований контроль за забрудненням і попередження виникнення відходів, зменшення споживання невідновлюваної енергії, ефективніші й екологічно чистіші види транспорту та транспортування, заходи для покращення якості довкілля в міських зонах; покращення громадського здоров'я, безпеки тощо.

П’ятою програмою дій пропонується використовувати ринкові інструменти, механізми фінансової підтримки, горизонтальні інструменти, що містять статистичні дані, наукові дослідження, технологічний розвиток та інше. У програмі підкреслювалася важливість та доцільність створення та існування неурядових організацій. Багато уваги надавалось питанню екологічної освіти. П'ята програма екологічних заходів була досить успішною і зробила великий внесок у структурні зміни законодавства країн-учасниць.

Важливе значення для розвитку політики у сфері охорони довкілля разом із П'ятою програмою дій із довкілля мав і Амстердамський договір 1997 року [28], який увів принцип охорони 


\section{Проблеми \\ екологічного законодавства}

довкілля як принцип діяльності Європейського Союзу.

Ще одним неоціненним внеском у розвиток європейського права довкілля в період реалізації П'ятої програми дій став факт підписання в 1998 році Європейським Співтовариством разом з усіма державами-членами Орхуської конвенції про доступ до екологічної інформації, участь громадськості в ухваленні рішень і доступ до правосуддя з питань, що стосуються довкілля [29].

Варто зазначити, що саме на цьому рівні розпочинається активна робота по боротьбі зі зміною клімату. 21 грудня 1993 року ЄС ратифікував Рамкову конвенцію ООН про зміну клімату [30], яка набрала чинності 21 березня 1994 року. А вже

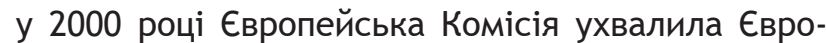
пейську програму зі зміни клімату [31]. Мета якої полягає у визначенні та розвитку всіх необхідних елементів стратегії $€$ д для імплементації Кіотського протоколу.

Шостий етап розпочинається 3 ухвалення у 2002 році Шостої програми дій $€ \mathrm{C}$ із довкілля [32]. Шоста програма дій із метою досягнення сталого розвитку передбачає координацію заходів у сфері довкілля не тільки держав-членів Європейського Союзу, але й держав-кандидатів та інших країн Європи й міжнародних екологічних організацій. Шоста програма визначає ключові екологічні завдання у таких сферах, як: зміна клімату, природа й біологічне різноманіття, довкілля, здоров'я і якість життя, природні ресурси й відходи.

Завдання у сфері довкілля, які визначає Шоста програма дій Європейського Союзу, полягають в інтеграції вимог щодо захисту довкілля у всю зовнішню політику Співтовариства; зміцненні міжнародного управління у сфері довкілля за допомогою поступового посилення багатосторонньої співпраці й інституційних рамок; орієнтації на швидку ратифікацію, ефективне дотримання та застосування міжнародних конвенцій і угод у сфері довкілля, де Європейський Союз $\epsilon$ Стороною; сприянні транскордонному екологічному співробітництву із сусідніми країнами й регіонами; сприянні узгодженості політики, за допомогою поєднання роботи, проведеної в межах різних конвенцій, включно з оцінкою взаємозв'язків між біорізноманіттям і зміною клімату та інтеграцію питань біорізноманіття в імплементацію Рамкової конвенції ООН про зміну клімату й Кіотського протоколу; розвитку і впровадженні чистих технологій, котрі сприяють більш ощадливому використанню природних ресурсів; виготовленні і продажу продукції, яка сприяє зниженню шкід- ливості відходів та мінімізації загрози забруднення довкілля; розробленні відповідних способів остаточного видалення небезпечних складників, призначених для утилізації відходів.

У травні 2002 року $Є С$ ратифікував Кіотський протокол до Рамкової Конвенції ООН про зміну клімату [33].

У цей період Європейський Союз розпочинає експериментувати з торгівлею емісією та впроваджує механізми, спрямовані на очищення, які полягають у закритті підприємств з екологічно шкідливими технологіями та інвестування в передові технології.

Сьомий етап розпочинається у 2013 році і триває досі. Він пов'язаний з ухваленням Сьомої програми дій із довкілля до 2020 року [34].

Сьома програма визначила такі пріоритетні завдання: ефективне використання ресурсів зеленої й конкурентоздатної низьковуглецевої економіки; забезпечення інвестування у сфері зміни клімату; підвищення рівня екологічної інтеграції та узгодженості політики; захист громадян ЄС від негативного впливу довкілля, пов'язаних з ним ризиків для здоров'я і благополуччя. Ця програма визначила засоби досягнення поставлених цілей.

Із метою захисту, збереження та підвищення природного капіталу $€ C$ повинно здійснити такі заходи: значно знизити вплив тиску на перехідних, прибережних та прісних водах; оновити принаймні 15 деградованих екосистем; скоротити забруднення повітря й негативного впливу на екосистеми та біорізноманіття. Всі сектори економіки повинні зробити свій внесок у скорочення викидів CO2. Держави-члени $\in C$ повинні розробити і ввести в дію довгострокові та економічно ефективні стратегії низьковуглецевого розвитку, що будуть спрямовані на скорочення викидів парникових газів на $80 \%$ та 95\% у 2050 році, порівняно з 1990 роком. Окрім цього, ЄС передбачає мінімізацію впливу небезпечних речовин, зокрема хімічних речовин у харчових продуктах.

Висновки. Підсумовуючи вищевикладений матеріал, необхідно зазначити, що політика гарантування екологічної безпеки в $\in C \in$ добре розвинутою й розпочалась ще наприкінці $60-x$ років. На сьогодні в $\in C \in$ всебічно розвинута система заходів, спрямованих на гарантування екологічної безпеки. Ядром цієї системи $\epsilon$ екологічне законодавство ЄС (директиви, рішення, програми дій). У межах програм дій із довкілля $Є С$ виробило індивідуальну екологічну політику й ухвалено значний масив нормативно-правових актів. I саме завдяки цьому значному масиву нормативно-правових 
актів держави-члени ЄС уносять зміни до національного законодавства з метою його узгодження.

Аналізуючи нормативні акти ЄС, стає зрозумілим, що екологічна безпека $\epsilon$ скоріше метою екологічної політики й досягається завдяки реалізації принципу сталого розвитку. Адже навіть зважаючи на положення Договору про функціонування ЄС [35], випливає, що цілями його політики у сфері охорони довкілля $\epsilon$ збереження, захист і поліпшення якості довкілля; охорона здоров'я населення; розумне та раціональне використання природних ресурсів; підтримка заходів на міжнародному рівні щодо вирішення регіональних або глобальних проблем довкілля, зокрема протидія зміні клімату. Така політика спрямована на досягнення високого рівня захисту і ґрунтується на принципах ужиття заходів перестороги, запобіжних заходів, відшкодування збитків, завданих довкіллю, i принципі «забруднювач платить». Звідси робимо висновок, що, на відміну від інших держав, держави-члени ЄС розуміють екологічну безпеку як мету, на досягнення якої спрямовані всі зусилля у сфері охорони довкілля, а тому Україна як суб'єкт міжнародних відносин, що зобов'язалась імплементувати вітчизняне законодавство до вимог законодавства Європейського Союзу, зобов'язана переглянути свої підходи до розуміння такої правової категорії, як «екологічна безпека».

\section{Література}

1. The world environment 1972-1992. London : Chapman and Hall, 1992. 884 p.

2. Клапцов В.М. Экологическая политика Евросоюза. Проблемы национальной стратегии. 2010. № 3(4). С. 147-161.

3. Лозо В.І. Європейська інтеграція і екологічна стратегія ЄС. Правові основи екологічної стратегії Європейського Союзу. Монографія. Харків : Право, 2008. $251 \mathrm{c}$.

4. Бізек В. Політика та право ЄС з питань, що стосуються довкілля: посібник. European Union Policy and Legislation on Environmental Matters. Київ, 2013. 163 c.

5. Малишева Н.Р. Закономірності побудови права Європейського Союзу. Екологічне право України. акад. курс: підруч. Әруге вид. / за заг. ред. Ю.С. Шемшученка. Київ : Юрид. думка, 2008. 720 с.

6. Council Directive 67/548/EEC of 27.06.1967 on the approximation of laws, regulations and administrative provisions relating to the classification, packaging and labelling of dangerous substances. OJ 196. 16.8.1967. P. 1-98.
7. Treaty on European Union, Luxembourg. Office for Official Publications of the European Communities. 1992. 253 p.

8. Stockholm Declaration on the Human Environment. U.N. Doc. A/CONF.48/14/Rev.1 (1972), reprinted in 11 I.L.M. 1417 (1972).

9. Краснова Ю.А. Право екологічної безпеки в Україні : дис. ... докт. юрид. наук : 12.00.06. Національний університет біоресурсів і природокористування України. Інститут економіко-правових досліджень НАН України. Київ, 2018. 589 с.

10. Правове регулювання відносин в сфері довкілля в Європейському Союзі та в Україні / за заг. ред. к.е.н. В.Г. Дідика. Київ, 2007. 579 с.

11. Директива Ради 70/220/ЄЕС від 20.03.1970 р. щодо наближення законів держав-членів щодо заходів проти забруднення повітря автомобілями. ОВ. L 76. 06.04.1970. P. 1-22.

12. Commission Directive 73/350/EEC of 07.11.1973 adapting to technical progress the Council Directive of 6 February 1970 on the approximation of 227 the laws of the Member States relating to the permissible sound level and the exhaust system of motor vehicles. Official Journal. L 321, 22.11.1973. P. 33-36.

13. Директива Ради 75/440/ЄЕС від 16.06.1975 р. щодо вимог до якості поверхневих вод, призначених для забору питної води в державах-членах Співтовариства. Official Journal. L 194 of 25.07.1975. Р. 26-31.

14. Директива Ради 76/160/ЄЕС від 08.12.1975 p. щодо якості води для купання. OB. L 31. 5.2.1976. P. 1.

15. Директива Ради 76/464/ЄEC від 04.05.1976 р. щодо забруднення, спричиненого деякими небезпечними речовинами, які скидаються у водне середовище Співтовариства. OJ. L 129. 18.5.1976. Р. 23.

16. Міжнародна конвенція про охорону Середземного моря від забруднення. Official Journal. L 240. 19/09/1977. Р. 0001-0002.

17. Друга програма дій Європейського Союзу із навколишнього середовища «Продовження та імплементація політики Європейського Співтовариства i програма дій із довкілля». ОJ. С 139. 13.6.77.

18. Директива Ради 80/779/ЄЕС від 15.07.1980 р. про граничні норми якості повітря та настановні величини сірчистого газу й зважених частинок. OJ L 229. 30.8.1980. Р. 30-48.

19. Директива Ради 80/51/ЄЕС від 20.12.1979 р. щодо обмеження шуму, що спричиняють дозвукові літаки. OJ L 18. 24.1.1980. Р. 26-28.

20. Конвенція про охорону дикої флори та фауни і природних середовищ існування в Європі від 19.09.1979 p. URL: https://zakon.rada.gov.ua/laws/ show/995_032\#Text. 
21. Конвенція про транскордонне забруднення повітря на великі відстані від 13.11.1979 р. Oj. L 171. 27.6.1981. Р. 13-24.

22. Третя програма дій Європейського союзу із довкілля. ОJ C 46. 17.2.83. р.

23. Директиви Ради 86/278/ЄЕС від 12.06.1986 р. про захист довкілля та, зокрема, ґрунту у випадках використання в сільському господарстві осаду стічних вод. ОJ L 181. 04/07/1986. Р. 6.

24. Рішення Комісії 85/71/ЄЕС від 21.12.1984 р. про список потенційно небезпечних хімічних речовин згідно з Директивою Ради 67/548/ЄЕС про зближення правових приписів, регламентів та адміністративних положень щодо класифікації, пакування й маркування небезпечних речовин. OJ L 30. 2.2.1985. P. 33-34.

25. Рішення Ради 85/613/ЄЕС від 20.12.1985 р. про ухвалення, від імені Спільноти, програм та заходів щодо скидання ртуті та кадмію, в рамках Конвенції про запобігання забрудненню морського середовища з джерел, розташованих на суші. OJ L 375. 31.12.1985. Р. 20-44.

26. Четверта програма дій ЄЕС у сфері довкілля (1987-1992) (Додаток до Резолюції 87/С 328/01). OJ C 328. 7.12.87.

27. П'ята програма дій Європейського союзу із довкілля. OJ C 138. 17.5.93.

28. Амстердамський договір про зміну Договору про Європейський Союз від 02.10.1997 р. Official Journal. C 340, 10.11.97.
29. Орхуська Конвенція про доступ до інформації, участь громадськості у процесі ухвалення рішень та доступ до правосуддя з питань, що стосуються довкілля від 25.06.1998 р. OJ L 124, 17.5.2005.

30. Рамкова Конвенція ООН про зміну клімату від 09.05.1992 р., ратифікована Законом України від 29.10.1996 р. № 435/96-ВР. Відомості Верховної Ради України. 1996. № 50. Ст. 277.

31. Європейська програма зі зміни клімату від 23 жовтня 2001 р. СОM(2001) 580.

32. Шоста програма дій Європейського союзу із довкілля від 22.07.2001 р. OJ L242, 10.9.2002.

33. Кіотський Протокол до Рамкової Конвенції про зміну клімату, ратифікована Законом України від 04.02.2004 р. № 1430-IV. Відомості Верховної Ради України. 2004. № 19. Ст. 261.

34. Сьома програма дій Європейського союзу із довкілля від 20.11.2013 р. OJ 2013. L354/171.

35. Treaty on the Functioning of the European Union (Consolidated version 2012). OJ C 326. 2012.

Краснова Ю. А., доктор юридичних наук, дочент, доцент кафедри аграрного, земельного та екологічного права імені академіка В. 3. Янчука Національного університету біоресурсів і природокористування України 